\title{
PENGARUH SUBSTITUSI UBI JALAR UNGU (Ipomoea batatas) SERTA PERBANDINGAN KACANG KORO (Canavalia ensiformis) DENGAN SUSU SKIM TERHADAP KARAKTERISTIK ES KRIM
}

\author{
Tantan Widiantara \\ Hasnelly \\ Erda Octadayani \\ Program Studi Teknologi Pangan, Fakultas Teknik, Universitas Pasundan, Jl. Dr.Setiabudi No 93, Bandung, 40153, \\ Indonesia \\ E-mail : tantan_widiantara@unpas.ac.id
}

\begin{abstract}
This research was aimed to determine and to assess the influence of the substitution of purple sweet potato and the comparison between skim milk and jack bean extract to the characteristic of purple sweet potato ice cream. The benefits of this research are to diversifying local food-based products, to increase the value of jack bean and purple sweet potato, and as the reference for the researchers about the process of making purple sweet potato ice cream. This research consist of two stages. The first stage is preliminary research, then followed by the second stage; main research. The experiment was designed using Randomized Block Design (RBD) with (3x3) factorial pattern which is consist of 2 (two) factors. The first factor is the substitution of purple sweet potato $(17,5 \% ; 22,5 \% ; 27,5 \%)$ and the second factor is the comparison between skim milk and jack bean extract (80\%:20\%; 70\%:30\%; 60\%:40\%), each combination was replicated three times. The results of the preliminary stages showed that jack bean extract contains HCN levels of $0.04968 \mathrm{mg} / \mathrm{kg}$ and protein content of $2.0499 \%$, antioxidant activity of purple sweet potato paste of $178.218 \mathrm{ppm}$. The results of the main research showed that the substitution of purple sweet potato had an affect on protein content, fat content, overrun, attributes of color, aroma, taste, and texture of the ice cream. The comparison of skim milk and jack bean extract affect the protein content, attributes of color, aroma, taste, and texture of ice cream. The interaction between the two effects on protein content, fat content, attributes of color, taste, and texture of purple sweet potato ice cream. The antioxidant activity of the highest protein sample was $791.403 \mathrm{ppm}$.
\end{abstract}

Keywords:drying temperatur, sucrose concentration, jelly candy

\section{Pendahuluan}

Indonesia dikenal sebagai negara agraris yang memiliki berbagai tanaman palawija. Salah satu tanaman palawija tersebut adalah ubi jalar. Ubi jalar merupakan komoditas sumber karbohidrat utama, setelah padi, jagung, dan ubi kayu, dan mempunyai peranan penting dalam penyediaan bahan pangan, bahan baku industri maupun pakan ternak. Menurut Hidayat dan Sugiyono (2007), ubi jalar berpotensi untuk dikembangkan menjadi sumber karbohidrat alternatif. Dilihat dari segi budidayanya, tanaman ini sangat potensial di Indonesia mengingat produksinya pada lima tahun terakhir mencapai 9.536.949 ton. Hingga tahun 2008, luas lahan ubi jalar di Indonesia mencapai 174,561 Ha dengan produksi mencapai 1.880.977 ton (Deptan, 2009).

Ubi jalar sendiri sangat beraneka ragam tergantung varietasnya. Salah satu varietas ubi jalar yang layak dikembangkan yaitu ubi jalar ungu (Ipomoea batatas). Selain memiliki potensi produktivitas yang besar, yaitu sekitar 15-20 ton/Ha (Yusuf dkk., 2003), ubi jalar ungu mengandung pigmen antosianin yang cukup besar dan lebih stabil bila dibandingkan sumber antosianin lainnya, seperti kubis merah, elderberries, blueberries dan jagung merah. Ubi jalar ungu juga memiliki aktivitas antioksidan baik secara in vivo dan in vitro, dapat berperan sebagai antihipertensi, memperbaiki kerusakan pada hati yang disebabkan oleh karbon tetraklorida (CCl4), menurunkan kadar gula darah postprandial serta berperan sebagai antimutagenik (Suda dkk., 2003). Warna merupakan salah satu penentu mutu pada produk pangan. Pangan yang memiliki nilai gizi yang tinggi, apabila tidak didukung dengan warna yang sesuai maka akan menurunkan mutu produk tersebut. Antosianin adalah pigmen yang menyebabkan warna merah, ungu dan biru. Pigmen antosianin dapat diperoleh dari tumbuhan dan hewan, salah satunya dari ubi jalar ungu (Ipomoea batatas L.). Antosianin digunakan sebagai pewarna alami pada produk makan dan minuman sehingga dapat mengganti penggunaan pewarna sintetis pada produk pangan, pigmen antosianin pada ubi jalar ungu juga dapat berperan sebagai penangkal radikal bebas yang berfungsi sebagai antioksidan dalam tubuh. Namun permintaan dan pemanfaatan ubi jalar di Indonesia masih cukup rendah. Hal ini disebabkan masih sedikitnya teknologi pengolahan pasca panen yang diterapkan, nilai ekonomis ubi jalar yang rendah, dan status ubi jalar sebagai bahan pangan inferior. Pemanfaatan ubi jalar masih terbatas sebagai bahan pangan yang dikonsumsi secara langsung dalam bentuk ubi goreng, ubi rebus, dan kolak, atau diolah menjadi produk setengah jadi diantaranya seperti mie dan tepung, sehingga perlu dilakukan pengembangan 
pengolahan dan penganekaragaman makanan sehingga dapat dimanfaatkan secara luas, berdaya guna, dan memberikan nilai ekonomi yang tinggi. Oleh karena itu dibutuhkan teknologi pengolahan yang mendukung pemanfaatan ubi jalar, seperti pengolahan ubi jalar menjadi es krim.

Es krim adalah makanan olahan yang lezat serta digemari masyarakat luas mulai dari kalangan anakanak, remaja hingga orang tua. Popularitas es krim semakin meningkat di negaranegara yang beriklim tropis atau panas seperti halnya di Indonesia. Konsumsi es krim di Indonesia berkisar 0,5 1t/orang/tahun dan diperkirakan semakin meningkat seiring dengan memasyarakatnya es krim (Setiadi, 2002). Pertumbuhan penduduk yang semakin meningkat dan adanya rasa, bentuk, ukuran yang bervariasi menjadikan permintaan es krim semakin meningkat.

Bahan dasar es krim pada umumnya adalah susu hewani yang merupakan emulsi minyak dalam air (Arbuckle, 2000). Ubi jalar ungu sangat rendah kandungan protein dan lemaknya, sehingga apabila digunakan sebagai bahan dasar pembuatan es krim maka perlu penambahan sumber protein dan lemak, sehingga dapat terbentuk emulsi (Luckman, dkk., 2014). Sumber protein yang dibutuhkan ini dapat ditambahkan dengan memanfaatkan bahan pangan lokal lainnya, yaitu kacang koro pedang. Kacang koro pedang (Canavalia ensiformis L.) adalah salah satu tanaman yang belum banyak dimanfaatkan di Indonesia. Padahal, kacang koro pedang sudah dikembangkan dan dikomersialisasikan sejak tahun 2006 di Indonesia. Keunggulan kacang koro pedang adalah dapat tumbuh di daerah marjinal seperti lahan dengan suhu dan kelembaban tinggi (Doss et al., 2011). Selain itu, iklim tropis menjadi habitat yang cocok bagi kacang koro pedang (Precoppe, 2005). Koro pedang memiliki potensi yang sangat besar menjadi produk pangan apabila ditinjau dari segi gizi dan syarat tumbuhnya. Dari kandungan gizi, koro pedang memiliki semua unsur gizi dengan nilai gizi yang cukup tinggi, yaitu karbohidrat $60,1 \%$, protein $30,36 \%$, dan serat $8,3 \%$ (Sudiyono, 2010). Koro pedang mempunyai potensi yang cukup besar untuk dikembangkan sebagai bahan pangan alternatif sumber protein karena keseimbangan asam aminonya sangat baik dan bioavaibilitasnya tinggi (Siti dkk., 2010). Permasalahan yang dihadapi dalam pemanfaatan koro pedang adalah adanya zat antigizi glukosida sianogenik yang menimbulkan cita rasa yang kurang disukai (Doss et al., 2011).

Koro pedang dapat diolah menjadi beberapa produk pangan seperti tepung koro pedang serta produk olahannya seperti cake, cookies dan produk bakery lainnya, kerupuk koro pedang, tempe koro pedang dan beberapa produk olahan lainnya. Koro pedang merupakan sumber protein nabati serta banyak mengandung vitamin B dan vitamin C (Sunaryono, 1984). Kandungan protein pada biji koro pedang sekitar 24\%. Biji koro pedang mengandung racun $\mathrm{HCN}$ sehingga harus direndam dan direbus terlebih dahulu untuk menghilangkan racun yang terkandung di dalamnya sebelum dikonsumsi (Rubatzky dan Yamaguchi, 1998).

Namun sayangnya potensi tersebut belum dikembangkan secara optimal oleh masyarakat sehingga pemanfaatannya masih relatif terbatas. Pemanfaatan yang masih terbatas menyebabkan koro pedang ini jarang ditanam oleh petani sehingga tingkat produksinya di Indonesia juga sangat rendah. Padahal jika dilihat dari syarat tumbuhnya, sebenarnya koro pedang dapat diproduksi dalam jumlah yang cukup tinggi yaitu berkisar antara 1 - 4,5 ton biji kering/ha (Suyanto, 2014). Oleh karena itu, untuk lebih mengoptimalkan pemanfaatan koro pedang sebagai bahan pangan, perlu dikembangkan sebuah inovasi baru yang dapat mengolah koro pedang menjadi produk yang enak, bergizi, dan memiliki nilai jual tinggi. Salah satu bentuk olahan sumber protein yang populer adalah es krim. Pengolahan koro pedang menjadi produk es krim akan meningkatkan kesukaan masyarakat, menambah nilai gizi dan memberikan nilai tambah dari koro pedang sebagai bahan pangan.

\section{Metode Penelitian}

Bahan yang digunakan pada penelitian ini adalah kacang koro pedang yang didapatkan dari Temanggung, ubi jalar ungu yang didapatkan dari Pasar Tradisional Gede Bage Bandung, susu murni, susu skim dan whipped cream, gelatin sapi, gula pasir, kuning telur, air. Bahan-bahan yang digunakan dalam analisis kadar protein adalah aquadest, larutan $\mathrm{NaOH}$, formalin $40 \%$, indikator PP $1 \%$ dan kalium oksalat jenuh. Bahan-bahan yang digunakan dalam analisis kadar lemak adalah pelarut lemak (hexana). Bahan-bahan yang digunakan dalam analisis kadar asam sianida adalah $\mathrm{NaCl}$ kering, larutan standar $\mathrm{NaCl} 0,1 \mathrm{~N}$, larutan $\mathrm{AgNo} 30,1 \mathrm{~N}$, larutan sampel, NH4CNS, AgNO3 padat, larutan $\mathrm{HNO} 3$ $6 \mathrm{~N}$, KBR, fluoresein, ferrri amonium sulfat, aquadest, HNO3 encer. Bahan-bahan yang digunakan dalam analisis aktivitas antioksidan adalah aquades, H2SO4 pekat, $\mathrm{CH} 3 \mathrm{COOH}$ pekat, serbuk $\mathrm{Mg}, \mathrm{HCl}$ pekat, $\mathrm{KCl}$, CH3COONa, FeCl3 1\%, metanol, dan DPPH (2,2Diphenyl-1-picrylhydrazyl).

Peralatan yang digunakan untuk penelitian ini adalah neraca, panci, spatula kayu, kompor, termometer, gelas ukur, kain saring, dan ice cream maker. Alat-alat yang digunakan dalam analisis kadar protein adalah neraca analitik, labu ukur $100 \mathrm{ml}$, batang pengaduk, corong, erlenmeyer, pipet tetes, klem, statif, dan buret. Alat-alat yang digunakan dalam analisis kadar lemak adalah kertas saring, kaca arloji, eksikator, kondensor, labu lemak, gelas ukur, soxhlet, oven, timbangan analitik, desikator. Alat-alat yang digunakan dalam analisis kadar asam sianida adalah statif, klem, corong kaca, kaca arloji, pengaduk kaca, buret asam, pipet tetes, neraca timbangan, labu ukur $500 \mathrm{ml}$, labu ukur $100 \mathrm{ml}$, erlenmeyer $100 \mathrm{ml}$, erlenmeyer $250 \mathrm{ml}$, beaker 
glass $250 \mathrm{ml}$, gelas ukur $50 \mathrm{ml}$. Alat-alat yang digunakan dalam analisis aktivitas antioksidan adalah kertas saring, alumunium foil, labu erlenmeyer $250 \mathrm{ml}$, corong kaca besar, corong kaca kecil, kertas tissue, pipet volumetri, pipet tetes, tabung reaksi, botol vial, gelas ukur, gelas kimia, kaca arloji, batang pengaduk, labu ukur $10 \mathrm{ml}$, neraca analitik, blender, ekstraktor, evaporator, dan spektrofotometer.

Metode penelitian yang dilakukan terdiri dari dua tahap yakni penelitian pendahuluan dan penelitian utama.

Penelitian pendahuluan yang dilakukan adalah sebagai berikut. Pembuatan sari kacang koro dengan menggunakan metode modifikasi dari Mulyani (2008). Pembuatan pasta ubi jalar ungu dengan menggunakan metode dari Filiyanti (2013) dengan modifikasi. Analisa bahan baku meliputi analisa kadar protein pada sari kacang koro dan analisa aktivitas antioksidan dari pasta ubi jalar ungu. Penelitian utama merupakan kelanjutan dari penelitian pendahuluan. Penelitian utama ini terdiri dari rancangan perlakuan, rancangan percobaan, rancangan analisis, dan rancangan respon.

\section{Hasil dan Pembahasan \\ Hasil Penelitian Pendahuluan}

Penelitian pendahuluan yang dilakukan bertujuan untuk membuat sari kacang koro dan pasta ubi jalar ungu, selanjutnya dilakukan analisis terhadap kadar asam sianida dan kadar protein pada sari kacang koro, dan dilakukan analisis terhadap aktivitas antioksidan dari pasta ubi jalar ungu. Hasil analisis pada penelitian pendahuluan dapat dilihat pada Tabel 1 .

Tabel 1. Hasil Analisis Sari Kacang Koro dan Pasta Ubi Jalar Ungu

\begin{tabular}{|c|c|c|}
\hline $\begin{array}{c}\text { Jenis } \\
\text { Bahan }\end{array}$ & $\begin{array}{c}\text { Komponen } \\
\text { Analisis }\end{array}$ & $\begin{array}{c}\text { Hasil } \\
\text { Analisis }\end{array}$ \\
\hline Sari & Asam & 0,04968 \\
Kacang & Sianida & $\mathrm{mg} / \mathrm{kg}$ \\
\cline { 2 - 3 } Koro & Protein & $2,0499 \%$ \\
\hline Pasta & & \\
Ubi Jalar & Aktivitas & 178,218 \\
Ungu & Antioksidan & $\mathrm{ppm}$ \\
\hline
\end{tabular}

\section{Hasil Penelitian Utama}

Penelitian utama merupakan kelanjutan dari penelitian pendahuluan. Penelitian utama ini terdiri dari rancangan perlakuan, rancangan percobaan, rancangan analisis, dan rancangan respon.

\section{Respon Kimia}

\section{a. Kadar Protein}

Berdasarkan hasil analisis variansi, menyatakan bahwa substitusi pasta ubi jalar ungu, perbandingan sari kacang koro dan susu skim yang berbeda, maupun interaksi antar keduanya berpengaruh terhadap kadar protein es krim ubi jalar ungu. Tabel dwi arah untuk hasil interaksi antara substitusi pasta ubi jalar ungu serta perbandingan sari kacang koro dan susu skim dapat dilihat pada Tabel 2.

Tabel 2. Dwi Arah untuk Interaksi Faktor U dan Faktor S Terhadap Kadar Protein (\%)

\begin{tabular}{|c|c|c|c|}
\hline \multirow{2}{*}{$\begin{array}{c}\text { Konsentra } \\
\text { si Ubi } \\
\text { Jalar Ungu } \\
\text { (u) }\end{array}$} & \multicolumn{3}{|c|}{$\begin{array}{c}\text { Perbandingan Susu Skim dan Sari } \\
\text { Kacang Koro (s) }\end{array}$} \\
\hline & $\begin{array}{c}\text { S1 } \\
(80 \% ; 20 \% \\
)\end{array}$ & $\begin{array}{c}\text { S1 } \\
(70 \% ; 30 \% \\
)\end{array}$ & $\begin{array}{c}\text { S1 } \\
(60 \% ; 400 \% \\
)^{2}\end{array}$ \\
\hline \multicolumn{4}{|c|}{ Nilai Rataan \pm Standar Deviasi } \\
\hline $\begin{array}{c}\mathrm{U1} \\
(\mathbf{1 7 , 5 \% )}\end{array}$ & $\begin{array}{l}\text { C } \\
2,627 \pm \\
C^{0,035}\end{array}$ & $\begin{array}{l}2,311 \pm \\
0,035 \\
\text { B }\end{array}$ & $\begin{array}{l}2,101 \pm \\
\\
a\end{array}$ \\
\hline $\begin{array}{c}\mathrm{U} 2 \\
(22,5 \%)\end{array}$ & $\begin{array}{l}1,226 \pm \\
C^{0,035}\end{array}$ & $\begin{array}{l}1,027 \pm \\
\text { B }^{0,131}\end{array}$ & $\begin{array}{cc}0,374 \pm \\
\\
a & 0,149\end{array}$ \\
\hline $\begin{array}{c}\mathrm{U3} \\
(27,5 \%)\end{array}$ & $\begin{array}{l}0,992 \pm \\
0,114 \\
C^{0}\end{array}$ & $\begin{array}{l}0,595 \pm \\
0,109 \\
\text { B }^{\text {A }}\end{array}$ & $\begin{array}{ll} & \mathrm{A} \\
& 0,181 \pm \\
& 0,027\end{array}$ \\
\hline
\end{tabular}

Keterangan: Setiap huruf yang berbeda menunjukkan perbedaan yang nyata pada taraf $5 \%$. Huruf kapital dibaca vertikal dan huruf kecil dibaca horizontal.

Berdasarkan Tabel 2, menunjukkan bahwa semakin tinggi persentase sari kacang koro dibanding susu skim, maka semakin rendah kadar protein es krim ubi jalar ungu. Hal ini disebabkan karena kadar protein pada susu skim lebih tinggi dibanding kadar protein pada sari kacang koro. Hal ini diperkuat dengan pernyataan Arbuckle (1972) yang menyatakan bahwa Milk Solid Non Fat atau susu skim mengandung kadar protein sebesar $36,7 \%$, serta hasil dari penelitian pendahuluan (Lampiran 9) yang menyatakan bahwa kadar protein sari kacang koro adalah sebesar 2,0499\%.

Semakin tinggi persentase sari kacang koro dibanding susu skim, maka semakin rendah kadar protein es krim ubi jalar ungu. Hal ini disebabkan karena kadar protein pada susu skim lebih tinggi dibanding kadar protein pada sari kacang koro. Hal ini diperkuat dengan pernyataan Arbuckle (1972) yang menyatakan bahwa Milk Solid Non Fat atau susu skim mengandung kadar protein sebesar 36,7\%, serta hasil dari penelitian pendahuluan (Lampiran 9) yang menyatakan bahwa kadar protein sari kacang koro adalah sebesar 2,0499\%.

Semakin tinggi konsentrasi pasta ubi jalar ungu, maka semakin rendah kadar protein es krim ubi jalar ungu, hal ini disebabkan karena substitusi pasta ubi jalar ungu yang meningkat akan menurunkan penggunaan susu murni, sedangkan kadar protein pada susu murni lebih tinggi jika dibandingkan dengan kadar protein pada ubi jalar ungu. Hal ini diperkuat oleh pernyataan Sulistiowati (2008) dalam penelitiannya mengenai perbandingan kadar protein dalam susu murni dan susu kemasan menggunakan metode spektrofotometri, yang 
menyatakan bahwa kadar protein pada susu murni berkisar antara 9,6598\% sampai $16,624 \%$ serta pernyataan Direktorat Gizi Departemen Kesehatan RI (1981) dalam Jamriyanti (2007) yang menyatakan bahwa kadar protein ubi jalar ungu hanya sebesar 1,8 gram per 100 gram bahan.

Hasil uji protein pada penelitian pada umumnya cukup rendah, hal ini juga dapat disebabkan karena pengolahan bahan pada proses pasteurisasi yang dimasak dengan suhu tinggi yang mengakibatkan denaturasi protein. Rendahnya kadar protein juga dapat disebabkan oleh adanya sebagian protein yang larut pada saat perendaman kacang koro pedang dengan air. Selain itu pengadukan ice cream mix (ICM) juga berpengaruh terhadap kadar protein. Pernyataan tersebut diperkuat oleh Poedjiadi (2005) bahwa protein dapat mengalami denaturasi akibat suhu tinggi, $\mathrm{pH}$ dan gerakan mekanik.

\section{b. Kadar Asam Sianida}

Berdasarkan perhitungan mengenai kadar asam sianida pada dua sampel terpilih, yaitu sampel dengan formulasi sari kacang koro tertinggi (u3s3) dan sampel dengan kadar protein tertinggi (u1s1), makadapat disimpulkan bahwa kisaran kadar asam sianida pada produk es krim adalah sebesar 0,036 mg/kg. Hasil analisis kadar asam sianida pada produk dapat dilihat pada Tabel 3.

Tabel 3. Kadar Asam Sianida Sampel dengan Persentase Sari Kacang Koro Tertinggi (u3s3) dan Sampel dengan Kadar Protein Tertinggi (u1s1) (mg/kg)

\begin{tabular}{|c|c|c|}
\hline \multirow{2}{*}{ Jenis Bahan } & Komponen & Hasil \\
\cline { 2 - 3 } & Analisis & Analisis \\
\hline $\begin{array}{c}\text { Es krimdengan } \\
\text { persentase sari kacang } \\
\text { koro tertinggi }\left(\mathrm{u}_{3} \mathrm{~s}_{3}\right)\end{array}$ & Asam sianida & 0,039 \\
\cline { 1 - 2 } $\begin{array}{c}\text { Es krimdengan kadar } \\
\text { protein tertinggi }\left(\mathrm{u}_{1} \mathrm{~s}_{1}\right)\end{array}$ & & 0,034 \\
\hline $\begin{array}{c}\text { Kadar Asam Sianida (Nilai Rataan } \pm \\
\text { Standar Deviasi) }\end{array}$ & $0,036 \pm 0,003$ \\
\hline
\end{tabular}

Kacang koro pedang yang digunakan sebagai bahan baku mengandung kadar asam sianida (HCN) sebesar $0,04968 \mathrm{mg} / \mathrm{kg}$, setelah dilakukan proses pengolahan menjadi produk es krim, kadar asam sianida (HCN) mengalami penurunan sebesar menjadi 0,036 $\mathrm{mg} / \mathrm{kg}$.

Menurut Marthia, dkk. (2013) penurunan kadar HCN pada kacang koro pedang dikarenakan terjadi difusi pada saat perendaman kacang koro pedang, dimana air masuk ke dalam sel dan HCN yang terdapat dalam sel akan keluar dan larut dalam air sebagai larutan perendaman. Kadar asam sianida dalam koro dapat berkurang karena beberapa proses pengolahan seperti pencucian dan perendaman dalam air dan penggilingan dengan air panas.

\section{c. Aktivitas Antioksidan}

Antioksidan secara umum didefinisikan sebagai senyawa yang dapat menunda, memperlambat dan mencegah proses oksidasi lipid. Dalam arti khusus, antioksidan adalah zat yang dapat menunda atau mencegah terjadinya reaksi oksidasi radikal bebas dalam oksidasi lipid (Kochhar dan Rosseli, 1990 dalam Sayuti dan Rina, 2015).

Antioksidan merupakan senyawa yang terdapat secara alami dalam bahan pangan. Senyawa ini berfungsi untuk melindungi bahan pangan dari kerusakan yang disebabkan terjadinya reaksi oksidasi lemak atau minyak yang sehingga bahan pangan yang berasa dan beraroma tengik (Andarwulan, 1995). Menurut Wildman (2001) antioksidan merupakan agen yang dapat membatasi efek dari reaksi oksidasi dalam tubuh. Secara langsung efek yang diberikan oleh antioksidan dalam tubuh, yaitu dengan mereduksi radikal bebas dalam tubuh, dan secara tidak langsung, yaitu dengan mencegah terjadinya pembentukan radikal.

Hasil analisis penelitian terhadap aktivitas antioksidan pada es krim ubi jalar ungu dengan kadar protein tertinggi (sampel u1s1) yaitu 791,403 ppm, yang berarti komponen antioksidan dalam es krim ubi jalar ungu mampu menghambat aktivitas radikal bebas (DPPH) 50\% pada konsetrasi 791,403 ppm. Aktivitas antioksidan pada es krim ubi jalar ungu ini lebih lemah jika dibandingkan aktivitas antioksidan pasta ubi jalar ungu pada penelitian pendahuluan.

Banyak faktor yang dapat mempengaruhi kekuatan antioksidan pada buah-buahan dan sayuran yang berwarna ungu, diantaranya adalah tingkat kematangan buah, berbagai proses pengolahan seperti pada proses pengalengan dan berbagai pengolahan (Sayuti dan Rina, 2015).

Aktivitas antioksidan dipengaruhi oleh banyak faktor seperti kandungan lipid, konsentrasi antioksidan, suhu, tekanan oksigen, dan komponen kimia dari makanan secara umum seperti protein dan air. Proses penghambatan antioksidan berbeda-beda tergantung dari struktur kimia dan variasi mekanisme. Dalam mekanisme ini yang paling penting adalah reaksi dengan radikal bebas lipid, yang membentuk produk non-aktif (Gordon, 2001 dalam Sayuti dan Rina, 2015).

Analisis aktivitas aktioksidan pada penelitian ini dilakukan dengan menggunakan metode DPPH. Metode DPPH (1,1 Diphenyl-2-picrylhidrazyl) merupakan salah satu uji untuk menentukan aktivitas antioksidan penangkap radikal. Menurut Molyneux (2004) dalam Bahriul dan Nurdin (2014), antioksidan bereaksi dengan 1,1difenil-2-pikrilhidrazil (DPPH) yang menstabilkan radikal bebas dan mereduksi DPPH. Kemudian DPPH akan bereaksi dengan atom hidrogen dari senyawa peredam radikal bebas membentuk 1,1-difenil-2pikrilhidrazin (DPPH) yang lebih stabil. Reagen DPPH yang bereaksi dengan antioksidan akan mengalami perubahan warna dari ungu ke kuning, intensitas warna tergantung kemampuan dari antioksidan.

Ubi jalar ungu mengandung pigmen antosianin dengan jumlah yang lebih tinggi dibandingkan dengan 
varietas lainnya. Antosianin dari ubi jalar ungu mempunyai fungsi sebagai antioksidan, anti kanker dan sebagai perlindungan terhadap kerusakan hati. Ubi jalar ungu dijadikan sebagai bahan baku penghasil antosianin pada beberapa industri pewarna makanan dan minuman. Selain itu ubi jalar ungu juga dijadikan sebagai bahan baku pada industri es krim, minuman beralkohol, pie dan roti (Winarti, 2010 dalam Sayuti dan Rina, 2015).

\section{d. Kadar Lemak}

Berdasarkan hasil analisis variansi pada, menyatakan bahwa faktor substitusi pasta ubi jalar ungu berpengaruh terhadap kadar lemak es krim, faktor perbandingan sari kacang koro dan susu skim yang berbeda tidak berpengaruh terhadap kadar lemak es krim, namun interaksi antara kedua faktor berpengaruh terhadap kadar lemak es krim ubi jalar ungu. Tabel dwi arah untuk interaksi antara substitusi pasta ubi jalar ungu serta perbandingan sari kacang koro dan susu skim dapat dilihat pada Tabel 4.

Tabel 4. Dwi Arah untuk Interaksi Faktor U dan Faktor S Terhadap Kadar Lemak (\%)

\begin{tabular}{|c|c|c|c|}
\hline \multirow{2}{*}{$\begin{array}{c}\text { Konsentrasi } \\
\text { Ubi Jalar } \\
\text { Ungu (u) }\end{array}$} & \multicolumn{3}{|c|}{$\begin{array}{c}\text { Perbandingan Susu Skim dan Sari Kacang } \\
\text { Koro (s) }\end{array}$} \\
\hline & $\begin{array}{c}\mathrm{S} 1 \\
(80 \% ; 20 \%)\end{array}$ & $\begin{array}{c}\mathrm{S} 1 \\
(\mathbf{7 0 \%} ; 30 \%)\end{array}$ & $\begin{array}{c}\text { S1 } \\
(60 \% ; 400 \%)\end{array}$ \\
\hline \multicolumn{4}{|c|}{ Nilai Rataan \pm Standar Deviasi } \\
\hline U1 $(17,5 \%)$ & $\begin{array}{l}\text { B } \\
12,398 \pm \\
0,203 \\
\text { A }\end{array}$ & $\begin{array}{l}10,407 \pm \\
1,026 \\
\text { a }\end{array}$ & $\begin{array}{l}\mathrm{A} \\
11,273 \pm 1,603 \\
\mathrm{a}\end{array}$ \\
\hline U2 $(22,5 \%)$ & $\begin{array}{c}\text { A } \\
8,706 \pm \\
\text { A } \\
0,506\end{array}$ & $\begin{array}{l}11,593 \pm \\
1,440 \\
c\end{array}$ & $\begin{array}{l}\mathrm{A} \\
11,232 \pm 1,128 \\
\text { bc }\end{array}$ \\
\hline U3 $(27,5 \%)$ & $\begin{array}{l}\text { A } \\
9,245 \pm \\
2,773\end{array}$ & $\begin{array}{l}\mathrm{A} \\
\mathrm{7} \\
\mathrm{a} \\
0,455 \pm\end{array}$ & $\begin{array}{l}\mathrm{A} \\
9,583 \pm 1,072 \\
\mathrm{a}\end{array}$ \\
\hline
\end{tabular}

Keterangan: Setiap huruf yang berbeda menunjukkan perbedaan yang nyata pada taraf 5\%. Huruf kapital dibaca vertikal dan huruf kecil dibaca horizontal.

\section{Respon Fisik}

a. Overrun

Berdasarkan hasil perhitungan analisis variansi, terhadap persentase overrun es krim ubi jalar ungu menunjukkan bahwa substitusi pasta ubi jalar ungu berpengaruh terhadap overrun es krim ubi jalar ungu, tetapi perbandingan susu skim dan sari kacang koro serta interaksi antara substitusi ubi jalar ungu dan perbandingan susu skim dan sari kacang koro tidak berpengaruh terhadap overrun es krim ubi jalar ungu. Hasil uji lanjut pengaruh substitusi pasta ubi jalar ungu dapat dilihat pada Tabel 5.
Tabel 5. Pengaruh Substitusi Pasta Ubi Jalar Ungu Terhadap Persentase Overrun Es Krim Ubi Jalar Ungu $(\%)$

\begin{tabular}{|c|c|c|}
\hline Perlakuan & $\begin{array}{c}\text { Rata-Rata } \\
\text { Perlakuan (Nilai } \\
\text { Rataan } \pm \text { Standar } \\
\text { Deviasi) }\end{array}$ & Taraf Nyata 5\% \\
\hline $\begin{array}{c}\mathrm{u} 1 \\
(17,5 \%)\end{array}$ & $47,391 \pm 2,618$ & $\mathrm{~b}$ \\
\hline $\begin{array}{c}\mathrm{u} 2 \\
(22,5 \%)\end{array}$ & $45,114 \pm 3,501$ & $\mathrm{ab}$ \\
\hline $\begin{array}{c}\mathrm{u} 3 \\
(27,5 \%)\end{array}$ & $42,485 \pm 3,150$ & $\mathrm{a}$ \\
\hline
\end{tabular}

Keterangan: Huruf yang berbeda pada setiap perlakuanmenunjukkan perbedaan yang nyata pada taraf $5 \%$.

Tabel 5 menunjukkan bahwa semakin meningkatnya substitusi pasta ubi jalar ungu, tingkat overrun es krim ubi jalar ungu yang cenderung menurun. Hal ini dikarenakan ubi jalar ungu mengalami proses gelatinisasi pati selama pemasakan yang mengakibatkan viskositas meningkat dan adonan menjadi kental. Adonan es krim yang kental akan mengakibatkan udara sulit masuk sehingga tidak terjadi kenaikan volume es krim atau overrun menurun. Hal ini sesuai pendapat Arbuckle dan Marshall (1996) yang menyatakan bahwa adonan yang kental akan menyebabkan overrun rendah, karena adonan mengalami kesulitan untuk mengembang dan udara sulit menembus masuk permukaan adonan.

\section{b. Waktu Leleh}

Berdasarkan hasil pengamatan serta perhitungan analisis variansi terhadap waktu leleh es krim ubi jalar ungu menunjukkan bahwa substitusi ubi jalar ungu, perbandingan susu skim dan sari kacang koro serta interaksi keduanya tidak berpengaruh terhadap waktu leleh es krim ubi jalar ungu. Hal ini dikarenakan penggunaan stabilizer berupa gelatin sapi yang dapat mencegah terbentuknya kristal es yang lebih besar, memberikan tekstur yang lembut dan mempertahankan pelelehan es krim pada saat dihidangkan. Hal ini diperkuat dengan pernyataan dari Eckles (1984) yang menyatakan bahwa fungsi dari stabilizer dalam pembuatan es krim adalah sebagai pengemulsi yaitu pengikatan globula yang berasal dari molekul lemak, air dan udara. Dengan demikian dapat mencegah terbentuknya kristal es yang lebih besar, memberikan tekstur yang lembut dan mempertahankan pelelehan es krim pada saat dihidangkan.

3. Respon Organoleptik

a. Warna

Berdasarkan hasil analisis variansi, menyatakan bahwa substitusi pasta ubi jalar ungu, perbandingan sari kacang koro dan susu skim yang berbeda, maupun interaksi antar keduanya berpengaruh terhadap atribut warna es krim ubi jalar ungu. Tabel dwi arah untuk hasil uji lanjut terhadap pengaruh interaksi antara kedua faktor dapat dilihat pada Tabel 6. 
Tabel 6. Dwi Arah untuk Interaksi Faktor U dan Faktor S Terhadap Uji Organoleptik Atribut Warna

\begin{tabular}{|c|c|c|c|}
\hline \multirow{2}{*}{$\begin{array}{c}\text { Konsentrasi } \\
\text { Ubi Jalar } \\
\text { Ungu (u) }\end{array}$} & \multicolumn{3}{|c|}{$\begin{array}{l}\text { Perbandingan Susu Skim dan Sari Kacang } \\
\text { Koro (s) }\end{array}$} \\
\hline & $\begin{array}{c}\mathrm{S1} \\
(80 \% ; 20 \%)\end{array}$ & $\begin{array}{c}\mathrm{S1} \\
(\mathbf{7 0 \%} ; \mathbf{3 0 \%})\end{array}$ & $\begin{array}{c}\text { S1 } \\
(60 \% ; 400 \%)\end{array}$ \\
\hline \multicolumn{4}{|c|}{ Nilai Rataan \pm Standar Deviasi } \\
\hline $\mathrm{U} 1(17,5 \%)$ & $\begin{array}{c}\mathrm{A} \\
3,833 \pm \\
0,186 \\
\mathrm{~A}\end{array}$ & $\begin{array}{c}\mathrm{A} \\
3,978 \pm \\
0,217 \\
\mathrm{a}\end{array}$ & $\begin{array}{c}\text { A } \\
4,022 \pm 0,184 \\
\mathrm{a}\end{array}$ \\
\hline $\mathrm{U} 2(22,5 \%)$ & $\begin{array}{c}\mathrm{B} \\
4,500 \pm \\
0,100 \\
\mathrm{~B}\end{array}$ & $\begin{array}{c}\mathrm{A} \\
3,933 \pm \\
0,058 \\
\mathrm{a}\end{array}$ & $\begin{array}{c}\text { B } \\
5,122 \pm 0,164 \\
\text { c }\end{array}$ \\
\hline U3 $(27,5 \%)$ & $\begin{array}{c}\mathrm{C} \\
4,856 \pm \\
0,135 \\
\mathrm{~A}\end{array}$ & $\begin{array}{c}\mathrm{B} \\
5,167 \pm \\
0,133 \\
\mathrm{Ab}\end{array}$ & $\begin{array}{c}\text { B } \\
5,300 \pm 0,203 \\
b\end{array}$ \\
\hline
\end{tabular}

Keterangan: Setiap huruf yang berbeda menunjukkan perbedaan yang nyata pada taraf 5\%. Huruf kapital dibaca vertikal dan huruf kecil dibaca horizontal.

Berdasarkan Tabel 6, semakin meningkatnya konsentrasi ubi jalar ungu pada perbandingan antara susu skim dan sari kacang koro yang tetap, terjadi perbedaan yang nyata pada sampel s1, s2, maupun s3 dalam hal atribut warna es krim ubi jalar ungu. Hal ini dikarenakan semakin banyak pasta ubi jalar ungu yang digunakan pada proses pembuatan es krim, maka akan semakin banyak atau pekat warna ungu dari es krim yang dihasilkan. Warna ungu yang berasal dari pigmen antosianin pada ubi jalar ungu menentukan kualitas warna dari es krim ubi jalar ungu, sehingga panelis menilai es krim ubi jalar ungu dengan perlakuan u3 (substitusi ubi jalar ungu tertinggi, yakni sebesar 27,5\%) sebagai es krim ubi jalar ungu dengan kualitas terbaik dari segi atribut warna.

Warna dari es krim ubi jalar ungu yang dihasilkan pada penelitian ini adalah ungu. Warna ungu berasal dari antosianin dalam ubi jalar ungu. Besar kandungan antosianin dalam ubi jalar ungu tergantung pada intensitas warna ungu pada ubi jalar ungu, semakin pekat warna ungu ubi maka kandungan antosianin semakin tinggi (Kumalaningsih, 2006). Antosianin merupakan pewarna alami yang tersebar luas dalam tumbuhan (bunga, buahbuahan, sayuran, dan ubi-ubian. Antosianin diketahui dapat berfungsi sebagai antioksidan (Yudiono, 2011).

\section{b. Aroma}

Berdasarkan hasil analisis variansi, menyatakan bahwa faktor substitusi pasta ubi jalar ungu serta faktor perbandingan sari kacang koro dan susu skim yang berbeda berpengaruh terhadap aroma es krim ubi jalar ungu, namun interaksi antara kedua faktor tidak berpengaruh terhadap aroma es krim ubi jalar ungu. Hasil uji lanjut Duncan terhadap pengaruh substitusi pasta ubi jalar ungu terhadap aroma es krim ubi jalar ungu dapat dilihat pada Tabel 7.
Tabel 7. Pengaruh Substitusi Pasta Ubi Jalar Ungu Terhadap Aroma Es Krim Ubi Jalar Ungu

\begin{tabular}{|c|c|c|}
\hline Perlakuan & $\begin{array}{c}\text { Rata-Rata } \\
\text { Perlakuan (Nilai } \\
\text { Rataan } \pm \text { Standar } \\
\text { Deviasi) }\end{array}$ & Taraf Nyata 5\% \\
\hline $\begin{array}{c}\mathrm{u} 1 \\
(17,5 \%)\end{array}$ & $4,196 \pm 0,086$ & $\mathrm{a}$ \\
\hline $\begin{array}{c}\mathrm{u} 2 \\
(22,5 \%)\end{array}$ & $4,452 \pm 0,069$ & $\mathrm{~b}$ \\
\hline $\begin{array}{c}\mathrm{u} 3 \\
(27,5 \%)\end{array}$ & $4,381 \pm 0,120$ & $\mathrm{~b}$ \\
\hline
\end{tabular}

Keterangan: Huruf yang berbeda pada setiap perlakuan menunjukkan perbedaan yang nyata pada taraf $5 \%$.

Hasil uji lanjut Duncan terhadap pengaruh perbandingan susu skim dan sari kacang koro terhadap aroma es krim ubi jalar ungu dapat dilihat pada Tabel 8.

Tabel 8. Pengaruh Perbandingan Susu Skim dan Sari Kacang Koro Terhadap Aroma Es Krim Ubi Jalar Ungu

\begin{tabular}{|c|c|c|}
\hline Perlakuan & $\begin{array}{c}\text { Rata-Rata } \\
\text { Perlakuan (Nilai } \\
\text { Rataan } \pm \text { Standar } \\
\text { Deviasi) }\end{array}$ & Taraf Nyata 5\% \\
\hline $\begin{array}{c}\text { s } 1 \\
(80 \%: 20 \%\end{array}$ & $4,319 \pm 0,018$ & $\mathrm{a}$ \\
\hline $\mathrm{s} 2$ & $4,404 \pm 0,015$ & $\mathrm{ab}$ \\
\hline$(70 \%: 30 \%)$ & $4,307 \pm 0,025$ & $\mathrm{~b}$ \\
\hline s3 $: 40 \%)$ & $60 \%$ & $\mathrm{~b}$ \\
\hline
\end{tabular}

Keterangan: Huruf yang berbeda pada setiap perlakuan menunjukkan perbedaan yang nyata pada taraf $5 \%$.

Aroma merupakan parameter uji yang penting untuk dilakukan pada es krim ubi jalar ungu ini, mengingat kacang koro pedang yang memiliki bau langu yang kurang disukai jika proses pengolahannya kurang tepat. Penilaian panelis terhadap aroma es krim ubi jalar ungu yang mengandung kacang koro pedang ini berkisar antara 4,293 sampai 4,385 (agak suka). Proses pengolahan kacang koro pedang menjadi es krim ubi jalar ungu memiliki aroma yang tidak langu, sehingga pengembangan lebih lanjut dengan penambahan flavor dan perisa akan menjadi hal yang mudah untuk dikembangkan.

Aroma es krim ubi jalar ungu akan berubah jika selama proses ditambahkan zat atau bahan cita rasa yang memiliki aroma yang dapat menutupi aroma kacang koro pedang, sehingga aroma yang dihasilkan dari es krim ubi jalar ungu adalah aroma ubi jalar ungu, dan aroma susu murni serta whipped cream yang digunakan dalam tambahan membuat es krim. Pada dasarnya susu murni serta whipped cream yang digunakan adalah sebagai sumber lemak pada pembuatan es krim ubi jalar ungu yang mempunyai aroma lebih kuat dibandingkan aroma ubi jalar ungu dan sari kacang koro yang digunakan.

Menurut Mutiara (2000) dalam Cahyadi (2017), penambahan bahan penstabil mungkin mengakibatkan terperangkapnya sebagian komponen aroma di dalam adonan, terutama bila adonan tersebut mempunyai 
kekentalan yang lebih tinggi. Semakin tinggi penambahan sukrosa maka semakin disukai oleh panelis. Menurut Marlindawati (2016) dalam Cahyadi (2017) hal tersebut disebabkan semakin tinggi kadar sukrosa semakin mendominasi aroma sukrosa pada suatu produk.

\section{Rasa}

Berdasarkan hasil analisis variansi, menyatakan bahwa substitusi pasta ubi jalar ungu, perbandingan sari kacang koro dan susu skim yang berbeda, maupun interaksi antar keduanya berpengaruh terhadap rasa es krim ubi jalar ungu. Tabel dwi arah untuk hasil uji lanjut pengaruh interaksi antara substitusi pasta ubi jalar ungu serta perbandingan sari kacang koro dan susu skim dapat dilihat pada Tabel 9.

Tabel 9. Dwi Arah untuk Interaksi Faktor U dan Faktor S Terhadap Uji Organoleptik Atribut Rasa

\begin{tabular}{|c|c|c|c|}
\hline \multirow{2}{*}{$\begin{array}{c}\text { Konsentrasi } \\
\text { Ubi Jalar } \\
\text { Ungu (u) }\end{array}$} & \multicolumn{3}{|c|}{$\begin{array}{l}\text { Perbandingan Susu Skim dan Sari Kacang } \\
\text { Koro (s) }\end{array}$} \\
\hline & $\begin{array}{c}\mathrm{S1} \\
(80 \% ; 20 \%)\end{array}$ & $\begin{array}{c}\mathrm{S1} \\
(\mathbf{7 0 \%} ; 30 \%)\end{array}$ & $\begin{array}{c}\mathrm{S} 1 \\
(60 \% ; 400 \%)\end{array}$ \\
\hline \multicolumn{4}{|c|}{ Nilai Rataan \pm Standar Deviasi } \\
\hline U1 $(17,5 \%)$ & $\begin{array}{c}\mathrm{A} \\
4,656 \pm \\
0,222 \\
\mathrm{a} \\
\end{array}$ & $\begin{array}{c}\mathrm{A} \\
4,956 \pm \\
0,096 \\
\mathrm{a} \\
\end{array}$ & $\begin{array}{c}\mathrm{C} \\
4,500 \pm 0,088 \\
\mathrm{a}\end{array}$ \\
\hline U2 $(22,5 \%)$ & $\begin{array}{c}\mathrm{A} \\
4,800 \pm \\
0,208 \\
\mathrm{~b}\end{array}$ & $\begin{array}{c}\mathrm{A} \\
4,867 \pm \\
0,176 \\
\mathrm{~b}\end{array}$ & $\begin{array}{c}\text { A } \\
3,200 \pm 0,233 \\
\mathrm{a}\end{array}$ \\
\hline U3 $(27,5 \%)$ & $\begin{array}{c}\text { A } \\
4,856 \pm \\
0,139 \\
\text { c }\end{array}$ & $\begin{array}{c}\mathrm{A} \\
4,678 \pm \\
0,084 \\
\mathrm{~b}\end{array}$ & $\begin{array}{c}\mathrm{B} \\
4,200 \pm 0,000 \\
\mathrm{a}\end{array}$ \\
\hline
\end{tabular}

Keterangan: Setiap huruf yang berbeda menunjukkan perbedaan yang nyata pada taraf $5 \%$. Huruf kapital dibaca vertikal dan huruf kecil dibaca horizontal.

Berdasarkan Tabel 9, menunjukkan bahwa substitusi ubi jalar ungu yang semakin tinggi akan meningkatkan kesukaan panelis terhadap rasa es krim ubi jalar ungu. Rata-rata penilaian panelis terhadap rasa es krim ubi jalar ungu berkisar antara 3,200 sampai 4,956 (agak tidak suka sampai suka). Hal ini dikarenakan ubi jalar ungu memberikan rasa manis khas ubi jalar ungu, sehingga secara sensori dapat dirasakan oleh panelis. Perbedaan rasa yang dihasilkan juga dipengaruhi oleh substitusi ubi jalar ungu menggantikan susu murni, dimana semakin banyak konsentrasi susu murni maka es krim yang dihasilkan memiliki rasa manis. Hal ini karena susu memiliki rasa agak manis. Menurut Susilorini (2006), susu memiliki rasa agak manis karena terdapat kandungan laktosa pada susu. Selain itu penambahan ubi jalar ungu dengan konsentrasi yang berbeda juga berpengaruh terhadap rasa es krim karena ubi jalar ungu memiliki rasa khas ubi jalar ungu.

Es krim yang manis pada umumnya diinginkan oleh hampir setiap orang yang memakannya. Oleh karena itu, gula biasanya ditambahkan pada campuran es krim sebanyak 12-16\%. Gula akan melembutkan tekstur, meningkatkan kecocokan pada es krim, memperkaya rasa dan biasanya merupakan sumber termurah dari padatan es krim. Kegunaan lain dari gula adalah berperan pada penurunan titik beku sehingga pada temperatur yang sangat rendah masih terdapat air yang tidak membeku. Tanpa adanya air yang tidak beku tersebut, maka es krim akan menjadi sangat keras dan sangat sulit untuk disendok. Gula merupakan sumber pemanis yang paling banyak digunakan karena memberi rasa yang kuat. Nur (2012) menambahkan rasa pada es krim dipengaruhi oleh bahanbahan penyusun pada pembuatan es krim yaitu lemak susu, gula, CMC dan susu skim.

\section{Tekstur}

Berdasarkan perhitungan analisis variansi pada Lampiran 20, menyatakan bahwa substitusi pasta ubi jalar ungu, perbandingan sari kacang koro dan susu skim yang berbeda, maupun interaksi antar keduanya berpengaruh terhadap kadar protein es krim ubi jalar ungu. Tabel dwi arah untuk hasil uji lanjut pengaruh interaksi antara substitusi pasta ubi jalar ungu serta perbandingan sari kacang koro dan susu skim dapat dilihat pada Tabel 10 .

Tabel 10. Dwi Arah untuk Interaksi Faktor U dan Faktor S Terhadap Uji Organoleptik Atribut Tekstur

\begin{tabular}{|c|c|c|c|}
\hline \multirow{2}{*}{$\begin{array}{c}\text { Konsentrasi } \\
\text { Ubi Jalar } \\
\text { Ungu (u) }\end{array}$} & \multicolumn{3}{|c|}{$\begin{array}{c}\text { Perbandingan Susu Skim dan Sari Kacang } \\
\text { Koro (s) }\end{array}$} \\
\hline & $\begin{array}{c}\mathrm{S1} \\
(80 \% ; 20 \%)\end{array}$ & $\begin{array}{c}\text { S1 } \\
(70 \% ; 30 \%)\end{array}$ & $\begin{array}{c}\text { S1 } \\
(60 \% ; 400 \%)\end{array}$ \\
\hline \multicolumn{4}{|c|}{ Nilai Rataan \pm Standar Deviasi } \\
\hline U1 $(17,5 \%)$ & $\begin{array}{c}\mathrm{A} \\
4,367 \pm \\
0,120 \\
\mathrm{a}\end{array}$ & $\begin{array}{c}\mathrm{A} \\
4,678 \pm \\
0,051 \\
\mathrm{~b}\end{array}$ & $\begin{array}{c}\mathrm{C} \\
4,478 \pm 0,069 \\
\mathrm{a}\end{array}$ \\
\hline U2 $(22,5 \%)$ & $\begin{array}{c}\mathrm{B} \\
4,578 \pm \\
0,069 \\
\mathrm{~b}\end{array}$ & $\begin{array}{c}\mathrm{A} \\
4,667 \pm \\
0,000 \\
\mathrm{~b}\end{array}$ & $\begin{array}{c}\mathrm{A} \\
4,078 \pm 0,184 \\
\mathrm{a}\end{array}$ \\
\hline U3 $(27,5 \%)$ & $\begin{array}{c}\mathrm{C} \\
4,844 \pm \\
0,069 \\
\mathrm{~b}\end{array}$ & $\begin{array}{c}\mathrm{A} \\
4,744 \pm \\
0,069 \\
\mathrm{~b}\end{array}$ & $\begin{array}{c}\mathrm{BC} \\
4,356 \pm 0,084 \\
\mathrm{a}\end{array}$ \\
\hline
\end{tabular}

Keterangan: Setiap huruf yang berbeda menunjukkan perbedaan yang nyata pada taraf $5 \%$. Huruf kapital dibaca vertikal dan huruf kecil dibaca horizontal.

Berdasarkan hasil pengujian hedonik terhadap tekstur es krim ubi jalar ungu menunjukkan bahwa konsentrasi yang berbeda pada masingmasing faktor menghasilkan perbedaan terhadap kesukaan panelis terhadap tekstur es krim ubi jalar ungu. Penilaian panelis terhadap rasa es krim ubi jalar ungu berkisar antara 4,367 sampai 4,844 (agak suka sampai suka) sehingga dapat dikatakan bahwa penerimaan panelis terhadap tekstur es krim ubi jalar ungu ini cukup baik. Hal ini karena tekstur es krim dipengaruhi oleh sumber lemak yang digunakan, dimana lemak susu (krim) pada es krim berfungsi untuk menghasilkan karakteristik tekstur yang lembut, membantu memberikan bentuk dan kepadatan, serta memberikan sifat meleleh yang baik (Padaga dan Manik, 2005). Pada penelitian ini sumber lemak yang digunakan adalah susu murni dan whipped cream. 
Namun, pada penelitian ini tekstur yang dihasilkan dari es krim ubi jalar ungu tidak hanya berasal dari susu murni dan whipped cream tetapi juga dari bahan-bahan lain yang digunakan seperti pasta ubi jalar ungu. Faktor lain yang mempengaruhi adalah homogenisasi (pengadukan) yang kurang merata yang dapat menyebabkan pasta ubi jalar ungu terkadang membentuk gumpalan pasta kecil yang kurang disukai oleh beberapa panelis.

Tekstur es krim ditentukan dengan menggunakan indera peraba, perasa dan penglihatan ketika menilai penampilan dan mencicipi es krim tersebut. Tekstur yang diinginkan dalam es krim adalah lembut, creamy, dan homogen (Marshall \& Arbuckle, 1986).

Menurut Suprayitno, dkk. (2001), tekstur es krim dipengaruhi oleh ukuran dari kristal es, globula lemak, gelembung udara, dan kristal laktosa. Tekstur es krim yang baik adalah smooth (halus/ lembut), tidak keras, dan tampak mengkilap (Padaga dan Sawitri, 2005). Hal ini seiring dengan pendapat Suprayitno, dkk. (2001) tekstur yang buruk adalah greasy (terasa ada gumpalan lemak), grainy (terasa seperti tepung), flaky atau snowy (terasa ada serpihan es), lumpy (seperti jelly), dan sandy (berpasir).

Berdasarkan hasil penelitian, maka dapat disimpulkan bahwa:

1. Substitusi ubi jalar ungu berpengaruh terhadap kadar protein, kadar lemak, overrun, atribut warna, atribut aroma, atribut rasa, dan atribut tekstur es krim ubi jalar ungu.

2. Perbandingan susu skim dan sari kacang koro berpengaruh terhadap kadar protein, atribut warna, atribut aroma, atribut rasa, dan atribut tekstur es krim ubi jalar ungu.

3. Interaksi substitusi ubi jalar ungu dan perbandingan susu skim dan sari kacang koro berpengaruh terhadap kadar protein, kadar lemak, atribut warna, atribut rasa, dan atribut tekstur es krim ubi jalar ungu.

\section{Daftar Pustaka}

1. AOAC. 2005. Official Methods of Analysis of The Association Analytical Chemist. Washington DC: The Association Analytical Chemist Inc.

2. Arbuckle, W. S. 1986. Ice Cream. Westport: The AVI Publishing Company Inc.

3. Arbuckle, W. S. dan J. H. Frandsen. 1961. Ice Cream and Related Products. Westport: The AVI Publishing Company Inc.

4. Arbuckle, W.S. 2000. Ice Cream Third Edition. Westport: The Avi Publishing Company Inc.

5. Arbuckle. W. S. dan R. T. Mashall. 2000. Ice Cream Fifth Edition. New York: Chapman \& Hall.

6. Badan Pusat Statistik. 2008. Statistik Indonesia 2007 (Produksi Umbi-umbian di Indonesia). https://www.bps.go.id/. Tanggal akses: 31 Oktober 2017.

7. Bahriul, Putrawan, Nurdin Rahman, dan Anang Wahid M. Diah. 2014. Uji Aktivitas Antioksidan
Ekstrak Daun Salam (Syzgium polyanthum) dengan Menggunakan 1,1-Difenil-2Pikrihidrazil. Jurnal Pendidikan Kimia (FKIP). Universitas Tadulo. Palu.

8. Cahyadi, Wisnu, Tantan Widiantara dan P. S. Rahmawati. 2017. Penambahan Konsentrasi Bahan Penstabil dan Sukrosa Terhadap Karakteristik Sorbet Murbei Hitam. Jurnal Penelitian Vol. 4 No. 3. Program Studi Teknologi Pangan. Fakultas Teknik. Universitas Pasundan.

9. Departemen Pertanian. Data Produksi Ubi Jalar Ungu. 2009. http://www.deptan.go.id. Tanggal akses: 24 Agustus 2017.

10. Doss, A., M. Pugalenthi, dan V. Vadivel. 2011. Nutritional Evaluation of Wild Jack Bean (Canavalia ensiformis) Seeds in Different Locations of South India. Word Applied Sciences Journal 13(7): 16061612. https://www.idosi.org/wasj/was j13(7)/6.pdf. Tanggal akses: 30 Oktober 2017.

11. Filiyanti, Ita, Dian Rachmawanti Affandi dan Bambang Sigit Amanto. 2013. Kajian Penggunaan Susu Tempe dan Ubi Jalar Ungu Sebagai Pengganti Susu Skim Pada Pembuatan Es Krim Nabati Berbahan Dasar Santan Kelapa, Jurnal Teknosains Pangan Vol. 2 No. 2 April 2013. www.ilmupangan.fp.uns.ac.id. Tanggal akses: 20 Agustus 2017.

12. Jamriyanti, Ririn. 2007. Ubi Jalar Saatnya Menjadi Pilihan. http://www.beritiptek.com. Tanggal akses: 31 Oktober 2017.

13. Kartika, Bambang, Pudji H. dan Wahyu S. 1988. Pedoman Uji Inderawi Bahan Pangan. Yogyakarta: Pusat Antar Universitas Pangan dan Gizi.

14. Kumalaningsih, S. 2006. Antioksidan Alami. Surabaya: Trubus Agrisarana.

15. Luckman A, Y Praptiningsih, Tamtarini. 2014. Pembuatan Es krim Ekstrak Ubi Jalar Ungu (Ipomea batatas L) dengan Variasi Jumlah Penambahan Susu Full Cream dan Karagenan. Berkala Ilmiah Pertanian 1(1): XX-XX http://repository.unej.ac.id/bitst ream/handle/123456789/71012/ LUCKMAN\%20ADI\%20PRA MONO.pdf?sequence $=1$. Tanggal akses: 17 Juli 2017.

16. Marthia, Nabila, Tantan Widiantara, dan L. H. Afrianti. 2013. Penurunan Sianida Dalam Kacang Koro Pedang Putih (Canavalia ensiformis) dengan Berbagai Metode. Jurnal Penelitian Tugas Akhir. Program Studi Teknologi Pangan. Universitas Pasundan. Bandung.

17. Melyani, Lisda. 2008. Kajian Perbandingan Ekstraksi dan Konsentrasi Inulin Pada Pembuatan Minuman Sari Kacang Koro Pedang (Canavalia ensiformis). Tugas Akhir Fakultas Teknik. Universitas Pasundan. 
18. Padaga, Manik dan Manik Eirry Sawitri. 2005. Membuat Es Krim Yang Sehat. Surabaya: Trubus Agrisarana.

19. Poedjiadi, Anna dan F.M. Titin Supriyanti. 2005. Dasar-Dasar Biokimia Edisi Revisi. Jakarta: UIPress.

20. Precoppe M. 2005. Jack Bean - Wonder Bean Canavalia ensiformis. https://www.unihohenheim.de/www380/380a/L ectureNotes/Canavalia.pdf. Tanggal akses: 31 Oktober 2017.

21. Rubatzky, V. E. dan Yamaguchi. 1998. Sayuran Dunia, Prinsip, Produksi, dan Gizi. Bandung: ITB.

22. Sayuti, Kesuma dan Rina Yenrina. 2015. Antioksidan Alami dan Sintetik. Padang: Andalas University Press.

23. Setiadi, Aldi. 2002. Es Krim Campina Bidik Pasar Dengan "Hati". http://www.sinarharapan.com. Tanggal akses: 14 Juni 2018.

24. Suda I, T. Oki, M. Masuda, M. Kobayashi, Y. Nishiba, dan S. Furuta. 2003. Physiological Functionality of PurpleFleshed Sweet Potatoes Containing Anthocyanins and Their Utilization in Foods. JARQ, Vol. 37(3) :167-173. https://jurnal.ugm.ac.id/jgki/art icle/view/18859. Tanggal akses: 14 September 2017.

25. Sudiyono. 2010. Penggunaan Na2HCO3 untuk Mengurangi Kandungan Asam Sianida (HCN) Koro Benguk pada Pembuatan Koro Benguk Goreng. Agrika. $\quad$ Vol.4(1): 4853. eprints.ums.ac.id/43101/1/NAS

KAH\%20PUBLIKASI.pdf. Tanggal akses: 12 Oktober 2017

26. Sulistyawati, Wignyanto, dan Sri Kumalaningsih. 2012. Produksi Tepung Buah Lindur (Bruguiera gymnorrhiza Lamk.) Rendah Tanin dan HCN Sebagai Bahan Pangan Alternatif. Jurnal Teknologi Pertanian. Volume 13. Nomor 3. Hal $187-198$.

27. Susilorini, Tri Eko dan Manik Eirry Sawitri. 2006. Produk Olahan Susu. Jakarta: Penebar Swadaya.

28. Sulistiowati, Erna. 2008. Perbandingan Kadar Protein dalam Susu Sapi (Susu Murni) dengan Susu Kemasan Menggunakan Metode Spektrofotometri Sinar Tampak Sebagai Sumber Belajar Kimia Kelas XII SMA Pada Sub Materi Pokok Protein. Tugas Akhir. Program Studi Pendidikan Kimia, Fakultas Sains dan Teknologi, Universitas Islam Negeri Sunan Kalijaga Yogyakarta.

29. Sunaryono, H. 1984. Kunci Bercocok Tanam Sayur-Sayuran Penting Di Indonesia. Bandung: Sinar Baru.

30. Suprayitno. 2001. Mempelajari Penambahan Stabilizer dan Flavor Terhadap Stabilitas
Emulsi Serta Overrun Es Krim. Jurusan gizi masyarakat dan sumber daya keluarga. IPB

31. Suyanto, Olivia Chandra. 2014. Pengaruh Substitusi Koro Pedang (Canavalia ensiformis) Terhadap Sifat Fisikokimia dan Sensori Selai Kacang . Tugas Akhir. Universitas Katholik Soegijapranata.

32. Yudiono, Kukuk. 2011. Ekstraksi Antosianin dari Ubi Jalar Ungu (Ipomoea batatas cv. Ayamurasaki) dengan Teknik Ekstraksi Subcritical Water. Jurnal Teknologi Pangan Vol. 2, No. 1. Jurusan Teknologi Hasil Pertanian. Universitas Katolik Widya Karya. Malang. 